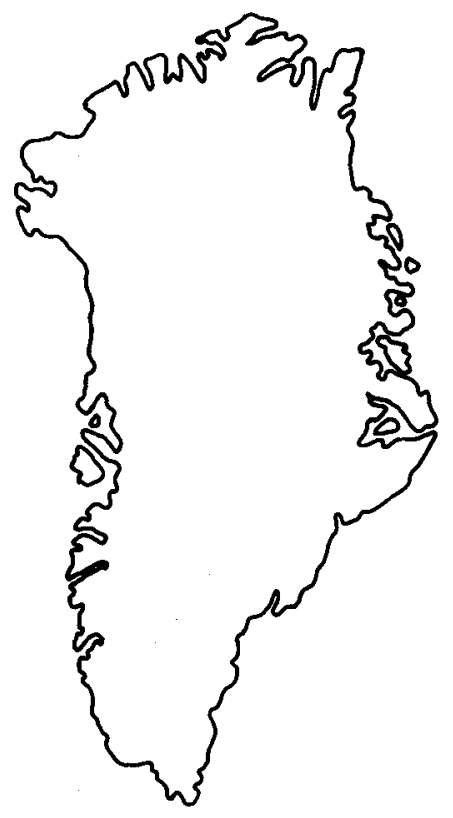

\title{
Crustal structure in West and South Greenland reflected by regional distribution patterns of calcium and potassium in stream sediment
}

\author{
Agnete Steenfelt
}

\begin{abstract}
The sampling of stream sediment for reconnaissance geochemical mapping has been completed for a large contiguous area from Uummannaq to Kap Farvel in West Greenland and the compilation of analytical data has commenced. Distribution patterns for the first two maps produced, those of calcium and potassium, outline provinces which are related to crustal features. The geochemical provinces can be interpreted to reflect differences in the depth of the exposed crustal segments. Geochemical boundaries occurring in geologically poorly known regions may be indicative of contacts between crustal blocks which have not previously been recognised.

In the appendix the quality of the analytical data used in the compilation of the geochemical maps is documented, and the procedure of calibration between data sets is presented.
\end{abstract}

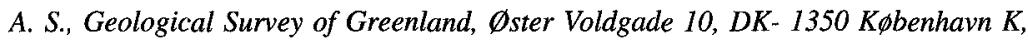
Denmark.

Geochemical maps based on analysis of surface samples such as stream sediment, till or soil may reflect lithotectonic units and major crustal domains, as demonstrated by examples from Greenland and elsewhere (e.g. Plant et al., 1984; Steenfelt, 1987, 1990; McMillan et al., 1990). However until now, stream sediment data from Greenland have not been compiled for large areas. In 1993 sampling and analysis of stream sediment for geochemical mapping have been completed over a $1200 \mathrm{~km}$ long contiguous area of West and South Greenland (Fig. 1), and the compilation of data sets to produce geochemical maps of that area has commenced.

In the compilation procedure it must be taken into consideration that the analytical data have been acquired over a long period of time and involve several analytical methods and laboratories, hence careful control of the data quality is necessary. The trace element data sets, in particular, need to be calibrated against each other. The major element data are the least variable, and the first two maps produced, those of $\mathrm{Ca}$ and $\mathrm{K}$, required little data correction.

The variation in the concentration levels displayed by $\mathrm{Ca}$ and $\mathrm{K}$ clearly reflects major crustal domains and their boundaries. The first part of this paper discusses the relation between the geochemical patterns and the exposed crustal level of these domains; the appendix documents the quality of the stream sediment data and explains the calibration procedure.

\section{Data acquisition}

The present coverage of West and South Greenland has been accomplished during regional surveys conducted over a period of 15 years (Steenfelt, 1994). The stream sediment and water samples were collected at a density of 1 sample per 20 to $30 \mathrm{~km}^{2}$ in West Greenland and 1 sample per 5 to $6 \mathrm{~km}^{2}$ in South Greenland. Each stream sediment sample is a composite of 3 to 10 sub-samples collected at different places in a stream bed along 10 to $50 \mathrm{~m}$ of its course.

The less than $0.1 \mathrm{~mm}$ grain size fractions of the samples have been analysed at a number of laboratories (Risø National Laboratory and Geological Survey of Greenland, both in Denmark; Sveriges Geologiska AB, Sweden; Bondar-Clegg and Activation Laboratories Ltd., both in Canada) using a number of analytical methods (delayed neutron counting for U, various forms of X-ray fluorescence techniques for major and trace elements, atomic absorption spectrometry and instrumental neutron activation analysis for a suite of major and trace elements). Samples from later years have been analysed for a suite of c. 45 major and trace elements and older samples have been reanalysed when required to obtain the same suite of elements for all samples. Between 35 and 40 of these elements have concentration levels suitable for display in geochemical maps. 
Table 1. Estimates for the composition of upper and lower crust, upper and bulk Archaean crust (Taylor \& McLennan, 1985)

\begin{tabular}{lrrrc}
\hline$\%$ & $\begin{array}{c}\text { lower } \\
\text { crust }\end{array}$ & $\begin{array}{c}\text { upper } \\
\text { crust }\end{array}$ & $\begin{array}{c}\text { upper } \\
\text { Archacan }\end{array}$ & $\begin{array}{c}\text { bulk } \\
\text { Archaean }\end{array}$ \\
\hline $\mathrm{SiO}_{2}$ & 54.4 & 66.0 & 60.1 & 57.0 \\
$\mathrm{TiO}_{2}$ & 1.0 & 0.5 & 0.8 & 1.0 \\
$\mathrm{Al}_{2} \mathrm{O}_{3}$ & 16.1 & 15.2 & 15.3 & 15.2 \\
$\mathrm{FeO}$ & 10.6 & 4.5 & 8.0 & 9.6 \\
$\mathrm{MgO}$ & 6.3 & 2.2 & 4.7 & 5.9 \\
$\mathrm{CaO}$ & 8.5 & 4.2 & 6.2 & 7.3 \\
$\mathrm{Na}_{2} \mathrm{O}$ & 2.8 & 3.9 & 3.3 & 3.0 \\
$\mathrm{~K}_{2} \mathrm{O}$ & 0.34 & 3.4 & 1.8 & 0.9 \\
\hline
\end{tabular}

\section{Potassium and calcium distribution in relation to crustal features}

The corrections made before plotting ensure that the concentration variations displayed by the maps are significant compositional changes. Moreover, it has been demonstrated for various regions in Greenland that the chemical composition of stream sediment closely reflects that of the underlying bedrock (e.g. Kalsbeek et al., 1974; Steenfelt \& Kunzendorf, 1979; Steenfelt, 1988; Steenfelt et al., 1992). The main compositional change from bedrock to stream sediment is that the proportion of weathering resistant minerals such as amphiboles, garnet, and accessory minerals (zircon, allanite etc.) increases in the stream sediment while the proportion of micas and feldspars decreases.

The Precambrian shield in West and South Greenland comprises three major crustal domains (Fig. 1): (1) The Archaean gneiss complex stabilised at c. $2.5 \mathrm{Ga}$ and hardly affected by later deformation, (2) the Ketilidian orogenic complex representing Proterozoic crust forming events and (3) the domain of extensive Proterozoic reworking of the Archaean gneiss complex (Nagssugtoqidian and Rinkian mobile belts). Evidence has been presented to suggest that the Archaean domain is composed of different terranes, i.e. crustal units with different ages and metamorphic histories, which were assembled in the late Archaean (Friend et al., 1988; Friend \& Nutman, 1994).

The maps of Ca and K (Figs $2 \& 3$ ) demonstrate that there is considerable variation in concentration levels over the Precambrian crust in West and South Greenland, and a number of provinces with fairly well defined boundaries may be distinguished (see also Steenfelt, 1994).

It is widely accepted that crustal differentiation leads to an increase in potassium and other lithophile elements at high crustal levels and a relative increase in calcium and other elements at lower crustal levels (e.g. Ramberg, 1951; Taylor \& McLennan, 1985; Table 1), although the nature of the processes contributing to the differentiation is still much debated. This implies that in West and South Greenland where about $80 \%$ of the rocks consist of grey orthogneisses the regional scale variations in $\mathrm{Ca}$ and $\mathrm{K}$ concentrations probably reflect changes in the level of the exposed part of the crust. On a local scale different lithological units are reflected, e.g. mafic supracrustal enclaves and carbonatites by high $\mathrm{Ca}$, granites by high $\mathrm{K}$.

The provinces distinguished in Figs $2 \& 3$ by changes in $\mathrm{Ca}$ and $\mathrm{K}$ concentration levels are characterised and tentatively interpreted in the following. The use of 'high' and 'low' in connection with crustal level is meant in a relative sense as it is realised that almost all of the exposed crust in West and South Greenland belongs to the upper crust in the division used by Taylor \& McLennan (1985) or upper and middle crust in the sense used by other authors (e.g. Windley, 1984).

The most readily obtained other estimate of the crustal depth at which the rocks were recrystallised is the regional metamorphic grade displayed in the geological maps (Fig. 1). However, high grade rocks are not always identified where they have been overprinted by retrograde metamorphism.

In the following discussion the 1:500 000 geological maps of West and South Greenland (Escher, 1971; Allaart, 1975, 1982) and map sheet descriptions (Kalsbeek \& Garde, 1989; Kalsbeek et al., 1990) are used as primary references supplemented by the author's field observations made during the collection of the stream sediment samples.

\section{Provinces outlined by variations in $\mathrm{Ca}$ and $\mathrm{K}$ concentrations}

\section{(1) Qarajaq Isfjord to Jakobshavn Isfjord}

General feature. Low $\mathrm{Ca}$, medium to high $\mathrm{K}$, i.e. high crustal level. This agrees with the general perception of the area; amphibolite facies gneisses prevail and no granulite facies rocks have been seen. The belt of high $\mathrm{K}$ across Arveprinsen Ejland and Pakiitsup Nunaa (at Ataa Sund in Fig. 1) is interpreted here to reflect the introduction of potassium to the tonalitic gneiss terrain by emplacement of granitic and lamprophyric veins, both common in the area (Kalsbeek, 1990).

Local feature. High Ca, low $\mathrm{K}$ is associated with Tertiary basalts on Nuussuaq, Saqqaq basic metavolcanic rocks and Boye Sø gabbro-anorthosite complex (Garde \& Steenfelt, in press). 


\section{(2) Jakobshavn Isfjord to Nordre Strømfjord}

General feature. Low to medium $\mathrm{Ca}$, low to medium $\mathrm{K}$, i.e. medium crustal level. This agrees with the predominance of amphibolite facies gneisses, with granulite facies gneiss occurring in smaller areas particularly in the south-western part. Units of supracrustal rocks with a large proportion of metasediments are common.

\section{(3) Nordre Strømfjord to Søndre Strømfjord, central part of Nagssugtoqidian orogen}

General feature. High $\mathrm{Ca}$, low $\mathrm{K}$, i.e. low crustal level, in agreement with the predominance of hypersthene-bearing plagioclase-hornblende gneisses in the northern part of this region.

Local feature south of Nordre Isortoq. A cluster of high $\mathrm{K}$, in the western part combined with high $\mathrm{Ca}$ and in the east combined with low $\mathrm{Ca}$. The western part of the cluster reflects an intrusive rock of shonkinitic affinity found by the author during 1993 field work, whereas samples from the eastern part also have high Th concentrations and are assumed to reflect granitic intrusions. The report by Steenfelt et al. (1993) contains the complete geochemical data on this region.

\section{(4) Søndre Strømfjord to Majorqaq}

General feature. High Ca, low to medium K, i.e. medium crustal level. According to the geological mapping (Allaart, 1982; Kalsbeek \& Garde, 1989) most of the region comprises granulite facies gneiss. The $\mathrm{Ca}$ and $\mathrm{K}$ variation agrees with this. The amphibolite facies area south of $67^{\circ} \mathrm{N}$ is not reflected in the surface geochemistry, which suggests amphibolite facies mineral assemblages were created here by hydrous retrogression of granulite facies gneisses. Occurrences of K-feldspar granitoid gneisses south-east of Søndre Strømfjord probably explain the elevated $\mathrm{K}$ values there. The Sukkertoppen ice cap and the ice cap lobe extending westwards from the Inland Ice hide some of the distribution patterns so that the size of the area with elevated $\mathrm{K}$ around latitude $66^{\circ} \mathrm{N}$ indicated round the edges of the ice caps is uncertain. The Majorqaq melt-water river makes up a sharp boundary between low $\mathrm{Ca}$ /medium $\mathrm{K}$ to the north and high $\mathrm{Ca} /$ low $\mathrm{K}$ to the south.

Local feature. A curved zone of low $\mathrm{Ca}$ and high $\mathrm{K}$ coincides with a fault/shear zone which follows the inner part of Evighedsfjord and continues southwards east of Maniitsoq. Small granitic intrusions were observed in the inner Evighedsfjord during sampling (Steenfelt et al., 1994b).

\section{(5) Majorqaq to Godthåbsfiord-Akia terrane}

General feature. High $\mathrm{Ca}$, low $\mathrm{K}$, i.e. low crustal level in agreement with the predominance of gneisses in granulite facies, or amphibolite facies formed by retrogression (Garde, 1989).

Local feature. A cluster of elevated $\mathrm{K}$ occurs in an area of lower $\mathrm{Ca}$ values centrally in the province. This may reflect compositional variation in the Taserssuaq tonalite which also includes granodioritic to granitic compositions, but may also indicate the presence of pegmatites.

\section{(6) Godthåbsfjord region - Akulleq terrane}

General feature. Low Ca, medium K, i.e. medium to high crustal level. Maps of airborne gamma-spectrometry (Steenfelt et al., 1991) show that the Akulleq belt contrasts with the terranes north and south of it by being enriched in Th and $\mathrm{U}$ as well as $\mathrm{K}$. The belt has been interpreted as a terrane of mixed origin squeezed between the Akia terrane to the north and the Tasiusarsuaq terrane to the south during continent collision (McGregor et al., 1991).

Local feature. High K in a NNE-trending belt reflects the late Archaean potassium-rich Qôrqut granite complex.

\section{(7) Ameralik to Frederikshåb Isblink - Tasiusarsuaq terrane}

General feature. Medium to high Ca, low $\mathrm{K}$, i.e. low to medium crustal level. The prevalence of granulite facies and retrogressed granulite facies south of the terrane boundary has been described by McGregor et al. (1991). Further to the south in this province (known as the Fiskenæsset and Bjørnesund regions) amphibolite facies rocks prevail (Kalsbeek, 1976) and accordingly, a gradient in the $\mathrm{Ca}$ concentrations from high values in the north to lower values in the south is noticeable (if the influence of the Fiskenæsset anorthosite complex and the Bjornesund amphibolites is disregarded). McGregor et al. (1991) interpret the change in metamorphic facies as reflecting a tilted crustal block with the deepest levels exposed in the northern part.

Local feature. High $\mathrm{K}$ and low $\mathrm{Ca}$ is associated with the Ilivertalik granite complex. 


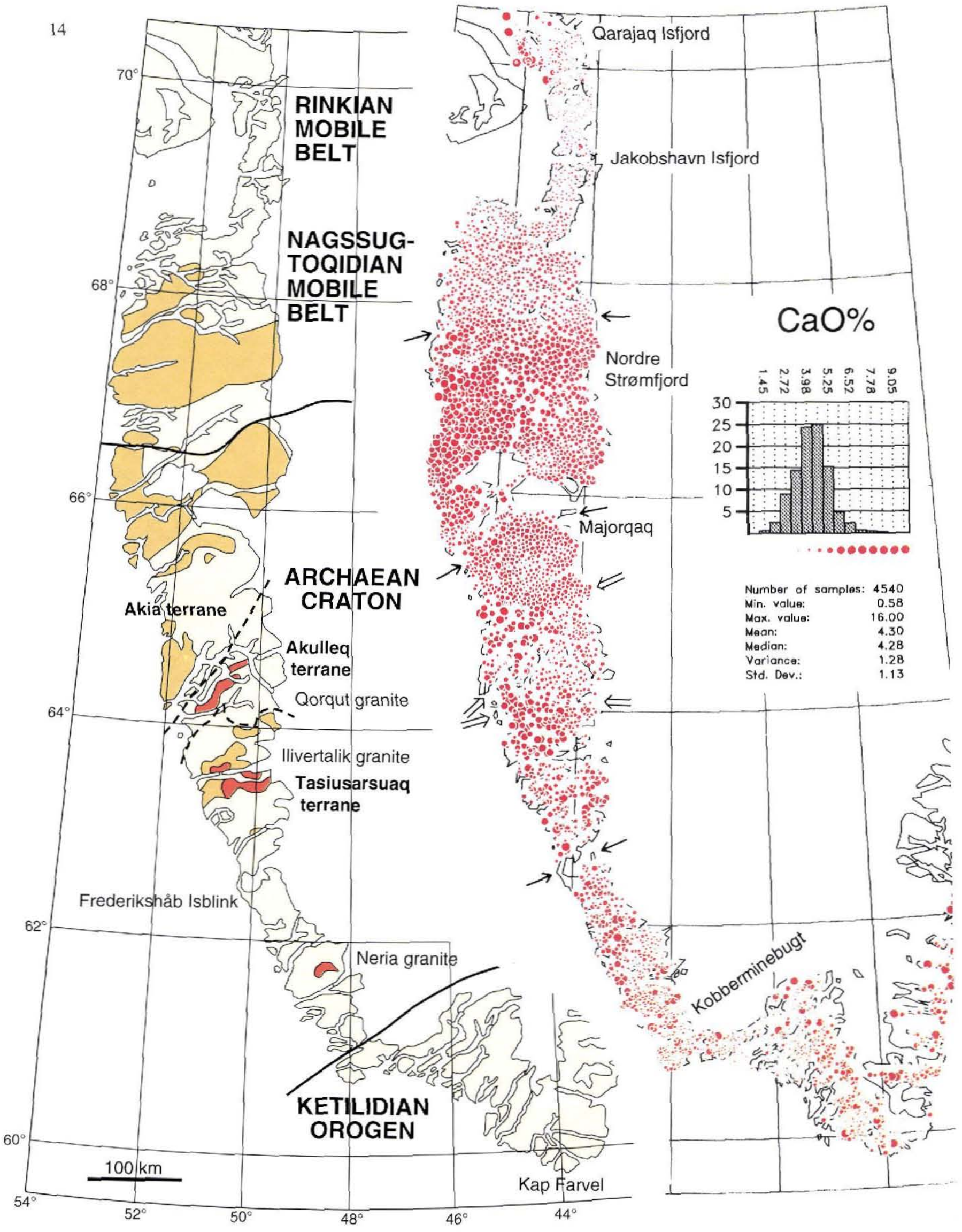



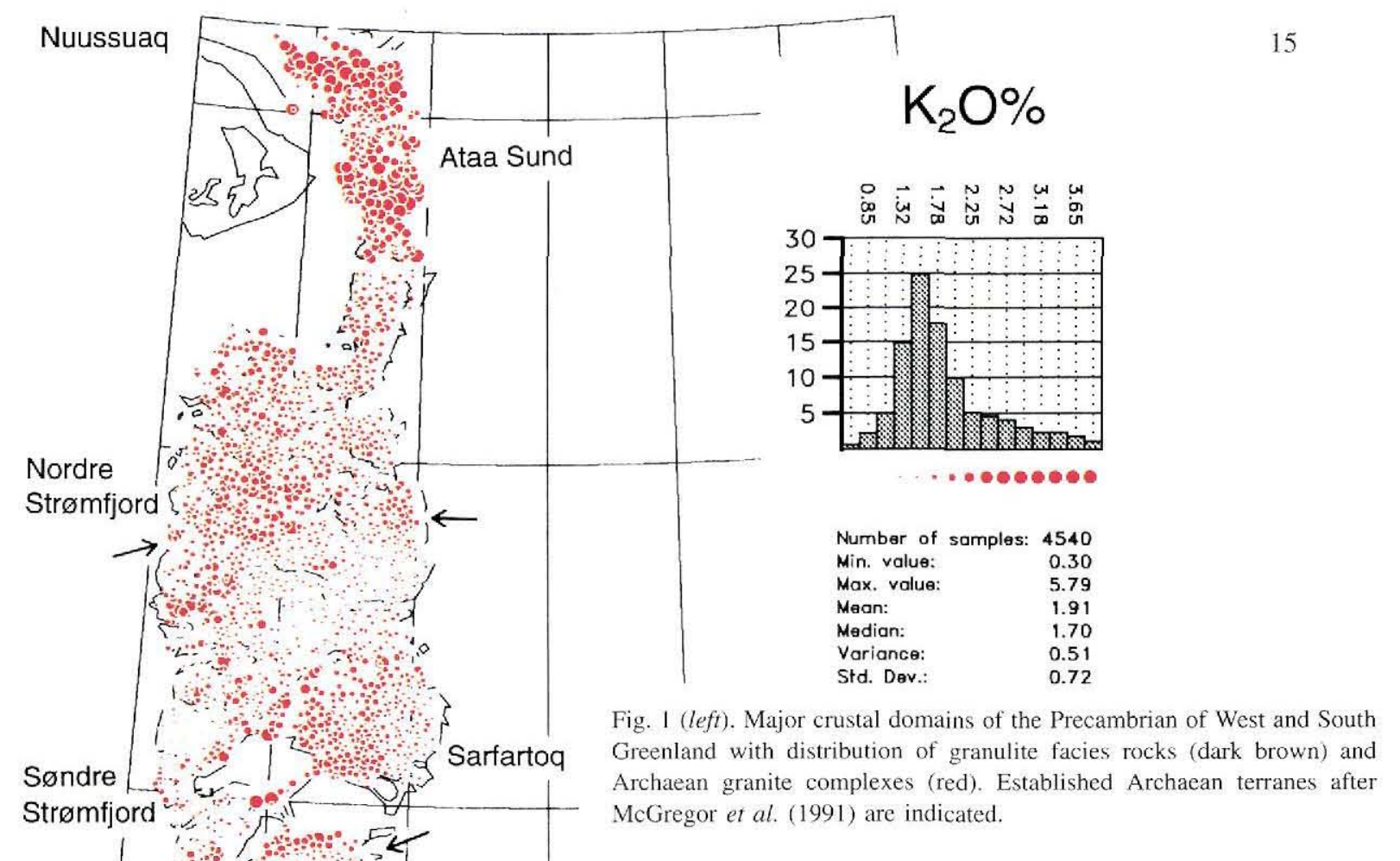
Fig. 2 (middle). Distribution map of $\mathrm{CaO}$ concentrations of the less than 0.1
Evighedsfjord $v_{2}, \ldots$ $\mathrm{mm}$ fraction of stream sediment. Analysis method: X-ray fluorescence spectrometry on fused discs. The values are calculated as volatile-free and adjusted as explained in the appendix.

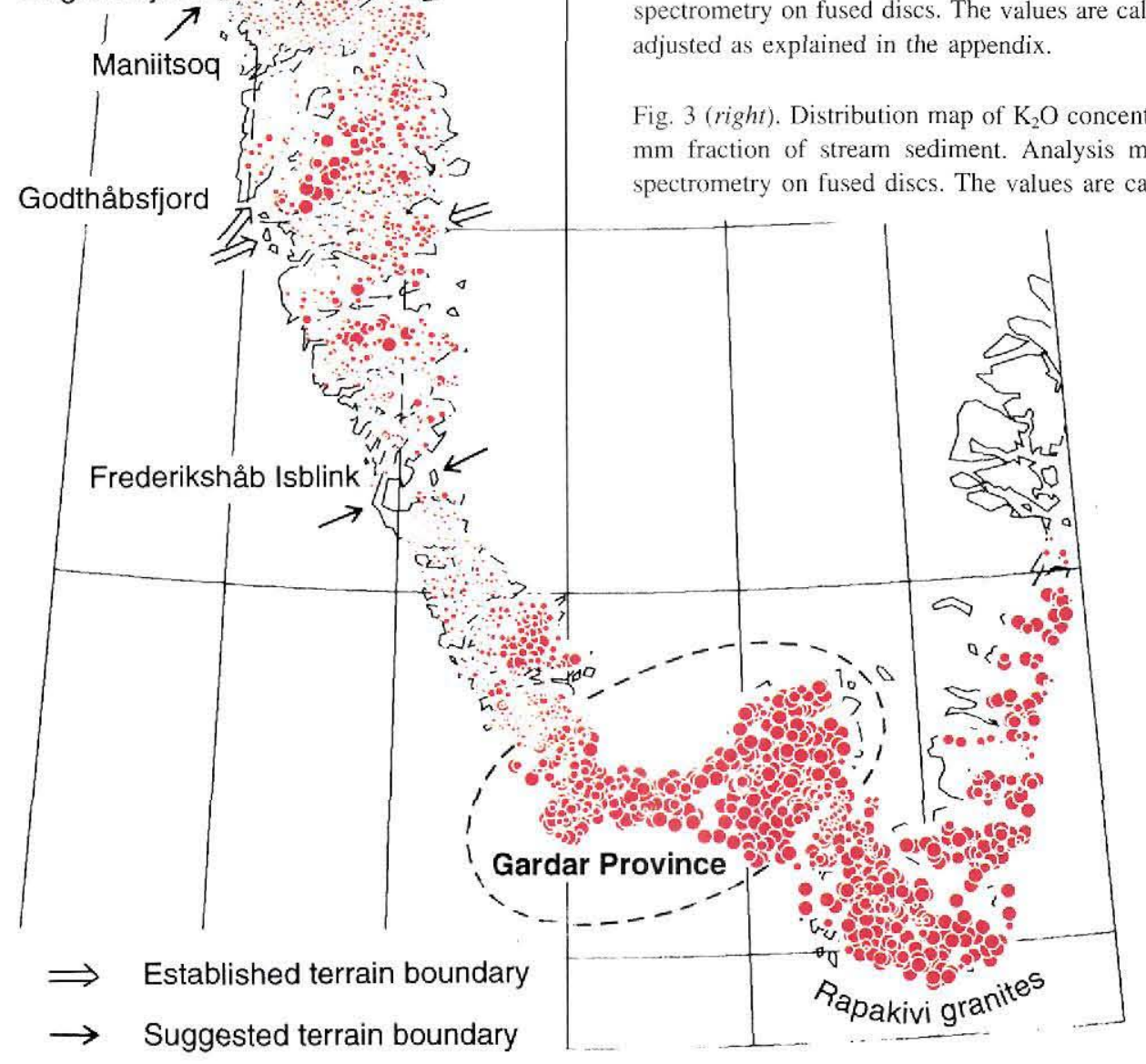




\section{(8) Frederikshåb Isblink to Kobberminebugt}

General feature. Medium to high $\mathrm{Ca}$ and low K, i.e. low to medium crustal level. All of this area appears as amphibolite facies on the geological map although the geochemical response as well as a low level of radioactivity in the northern part (Steenfelt et al. 1994) resembles that of granulite facies terrains elsewhere. The dominant rock type in the northern part is hornblende plagioclase gneiss. Hypersthene encountered in sand samples derived from the Frederikshåb Isblink glacier also indicates the presence of granulite facies rocks (Kalsbeek, 1976). Altogether, the crustal level immediately south of Frederikshåb Isblink appears to be lower than that of the Bjørnesund region north of the Isblink.

Local features. High $\mathrm{K}$ and low $\mathrm{Ca}$ is associated with the Archaean Neria granite (see also Steenfelt et al., 1994a) and with Proterozoic granites in the southernmost part of this province (see below).

\section{(9) Kobberminebugt to Kap Farvel - Ketilidian orogen}

General feature. Low $\mathrm{Ca}$, high $\mathrm{K}$, i.e. high crustal level. This region has a juvenile Proterozoic origin (Patchett \& Bridgwater, 1984; Kalsbeek \& Taylor, 1985) and is composed of a northern granite batholith province and a southern province of Proterozoic supracrustals intruded by post-orogenic rapakivi granites. Extra potassium has been added to the crust through alkaline magmatism (Gardar Province) of mid-Proterozoic age (Upton \& Emeleus, 1987).

Local feature. High $\mathrm{Ca}$ values are associated with metabasic volcanic and intrusive rocks.

\section{Interpretation of geochemical boundaries}

The above comparisons of the regional geochemical variations with the geological maps show that the distribution patterns generally correspond with the distribution of granulite facies and amphibolite facies rocks and with the occurrences of major granitic intrusions. However, the most interesting feature of the element distribution maps is that they reveal the existence of distinct and unexpected geochemical boundaries.

Two of the observed geochemical boundaries (Fig. 2) coincide with boundaries between different Archaean terranes (Fig. 1) recognised by Friend et al. (1988) and further described in e.g. McGregor et al. (1991). Therefore, it is suggested that other geochemical boundaries reflect hitherto unrecognised terrane boundaries. For ex- ample, the boundary across an east-west line subparallel with Nordre Strømfjord distinguished by a fairly abrupt change from a province of medium concentration levels of both $\mathrm{Ca}$ and $\mathrm{K}$ to a province with high concentrations of $\mathrm{Ca}$ and low concentration levels of $\mathrm{K}$, could reflect a terrane boundary. This boundary could be either Archaean or Proterozoic in age, as it separates two Archaean gneiss complexes, the northern of which is known to contain Proterozoic supracrustal units (Kalsbeek et al., 1987).

McGregor et al. (1991) discussed the possible positions of the so far unidentified northern boundary of the Akia terrane and southern boundary of the Tasiusarsuaq terrane. In the maps of $\mathrm{Ca}$ and $\mathrm{K}$ a concentration change is noted at Majorqaq which might represent the northern boundary of the Akia terrane. Friend \& Nutman (1994) and Kalsbeek (1993) have presented evidence for the existence of a terrane boundary in this area by pointing out that the age of granulite facies metamorphism in the area immediately north of the Majorqaq boundary differs from that of the Akia terrane.

The southern boundary of the Tasiusarsuaq terrane could be located at Frederikshåb Isblink where a change in crustal level is suggested by a combination of geochemical and lithological evidence as discussed in the section above. However, the geochemical boundary at Frederikshåb Isblink is not as well defined as those at Nordre Strømfjord and Majorqaq, respectively.

\section{Comments on the distribution of high $K$ values}

The Archaean gneisses are predominantly of tonalitic composition which is reflected by the generally low concentration level of $\mathrm{K}$ in stream sediment (Fig. 3). Two of the clusters of high $\mathrm{K}$ values in the Archaean domain can be ascribed to the occurrence of known late tectonic Archaean granite complexes, the Qôrqut and Ilivertalik complexes (see Kalsbeek \& Garde, 1989). The high K cluster at Neria reflects another, previously unrecognised, Archaean granite complex, the position of which in the history of terrane assembly in southern West Greenland has still to be ascertained.

High $\mathrm{K}$ values occurring north of $65^{\circ} \mathrm{N}$ do not reflect larger granite complexes. Field observations from these areas document the presence of granite pegmatites, granite veins and minor granite sheets, but the extent and frequency of such occurrences are usually not mapped systematically. This makes the information about $\mathrm{K}$ distribution provided by the stream sediment data very valuable in the estimation of the amount and extent of granitic magmatism to which the different crustal domains have been subjected.

The high $\mathrm{K}$ concentration of the accreted Proterozoic 
crust in South Greenland has been noted previously (Steenfelt, 1990), and a similar K enrichment is observed in till samples from Proterozoic regions in northern Fennoscandia (Bolviken of al. 1986) and southern Finland (Koljonen et al, 1992). The Ketilidian orogen is also characterised by high concentrations of other lithophile clements, particularly uranium (Armour-Brown et al., 1983). By contrast, Fig. 2 shows that Kenrichment is not associated with the Proterozoic magmatic event recognised in the Nordre Strømfjord region (Kalsbeek et al., 1987). The extent and nature of the Prolerozoic magmatic rocks are poorly known in this region, but the present data suggest that acid magmatism was limited.

\section{Concluding remarks}

The gcochemical distribution patterns displayed by $\mathrm{Ca}$ and $K$ agree with the concept that the Precambrian shield represents an assembly of different terrancs. However, the interpretations and comments must be regarded as preliminary, as they are based on only two (although petrogenetically very important) of the 35 to 40 chemical clements which are suitable for large scale compilations. The use of the additional element data will greatly improve the possibilities to distinguish boundaries between crustal units and interpret their relationships.

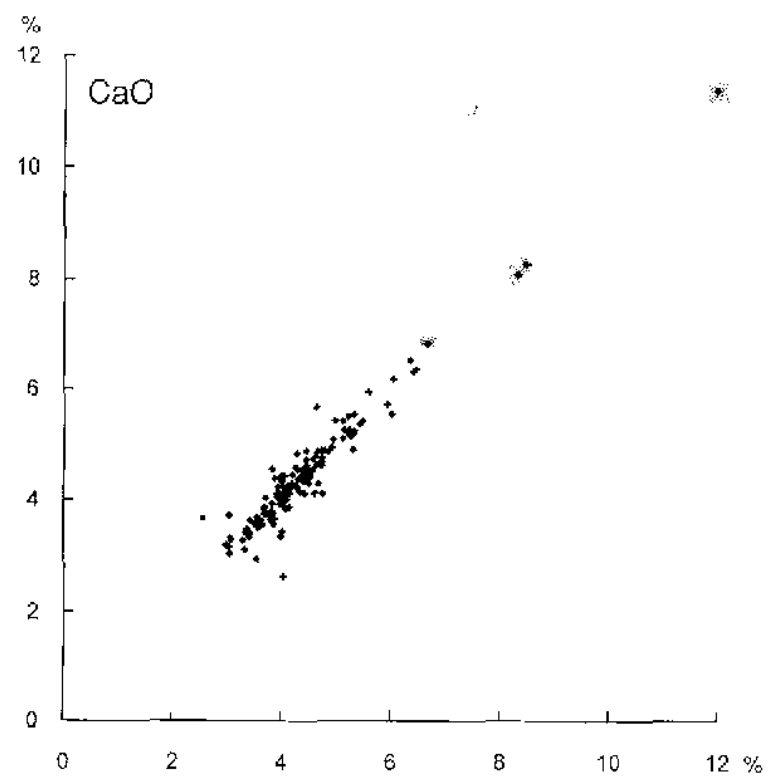

\section{Appendix}

Data quality

\section{Sampling}

The variability within a sample site of the chemical composition of stream sediment is tested by collecting and analysing duplicate samples from 5 to $[0 \%$ of the total number of sampling sites. The two samples are collected 10 to $50 \mathrm{~m}$ apart, sometimes by two different persons. The analyses of 145 samples and duplicates distributed over West Greenland from $62^{\circ}$ to $70^{\circ} \mathrm{N}$ are shown in Fig. 4. The difference between a sample and the duplicate is typically $2.5 \%$ relative (median) for $\mathrm{K}_{2} \mathrm{O}$ and is less than $10 \%$ in $95 \%$ of the 145 sample pairs. For $\mathrm{CaO}$ the relative difference is typically $4.5 \%$ and less than $15 \%$ in $95 \%$ of the cases. Fig. 4 also shows that the sampling error is small relative to the range of concentrations obtained over the entire area in West Greenland, and will not affect the significance of regional scale variations discussed in this presentation.

\section{Analysis}

In general, the compilation of all the different data sets requires a considerable amount of calibration due to analytical bias between laboratories and methods. However, the elements chosen for this presentation ( $\mathrm{Ca}$ and $\mathrm{K}$ ) make a fairly simple case in that all samples are analysed by the same method ( $X$-raty fluorescence on fused glass discs) at only two laboratories, Geological Survey of Greenland (GGU) and Activation Laboratories Ltd (Actlabs). The compatibility of the results has been examined in two ways. A set of five internal stream sediment standards has accompanied every batch of samples stabmitted for analysis since 1990, and two sets of samples have been analysed at both laboratories.

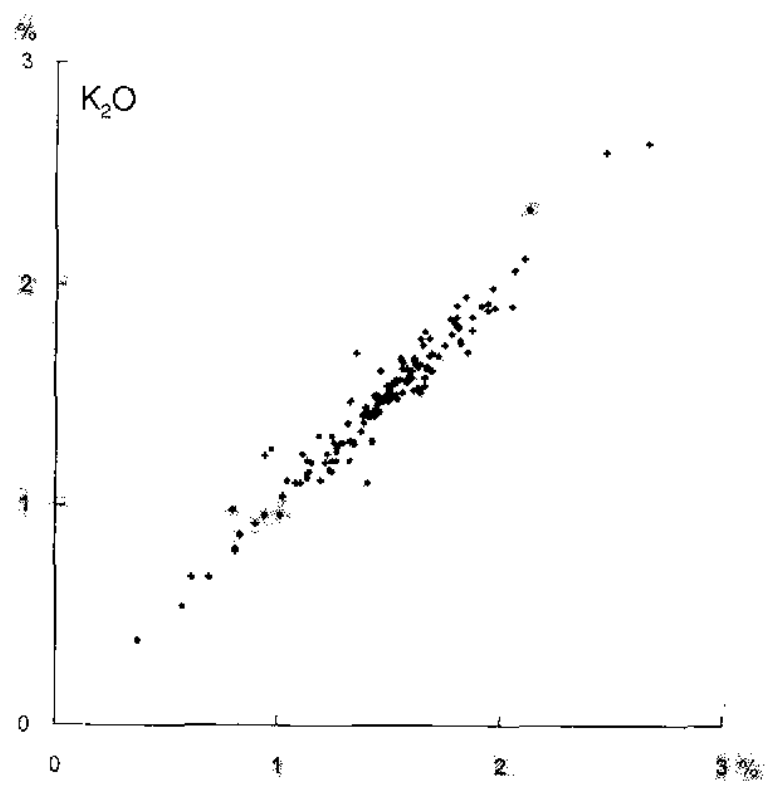

Fig. 4. Chemical variability within sampling sites. The diagrams for $\mathrm{CaO}(l e f)$ and $\mathrm{K}_{2} \mathrm{O}$ (right) show the analyses of pairs of samples collected at 145 sites in West Greeniand between $62^{\circ}$ and $70^{\circ} \mathrm{N}$. 


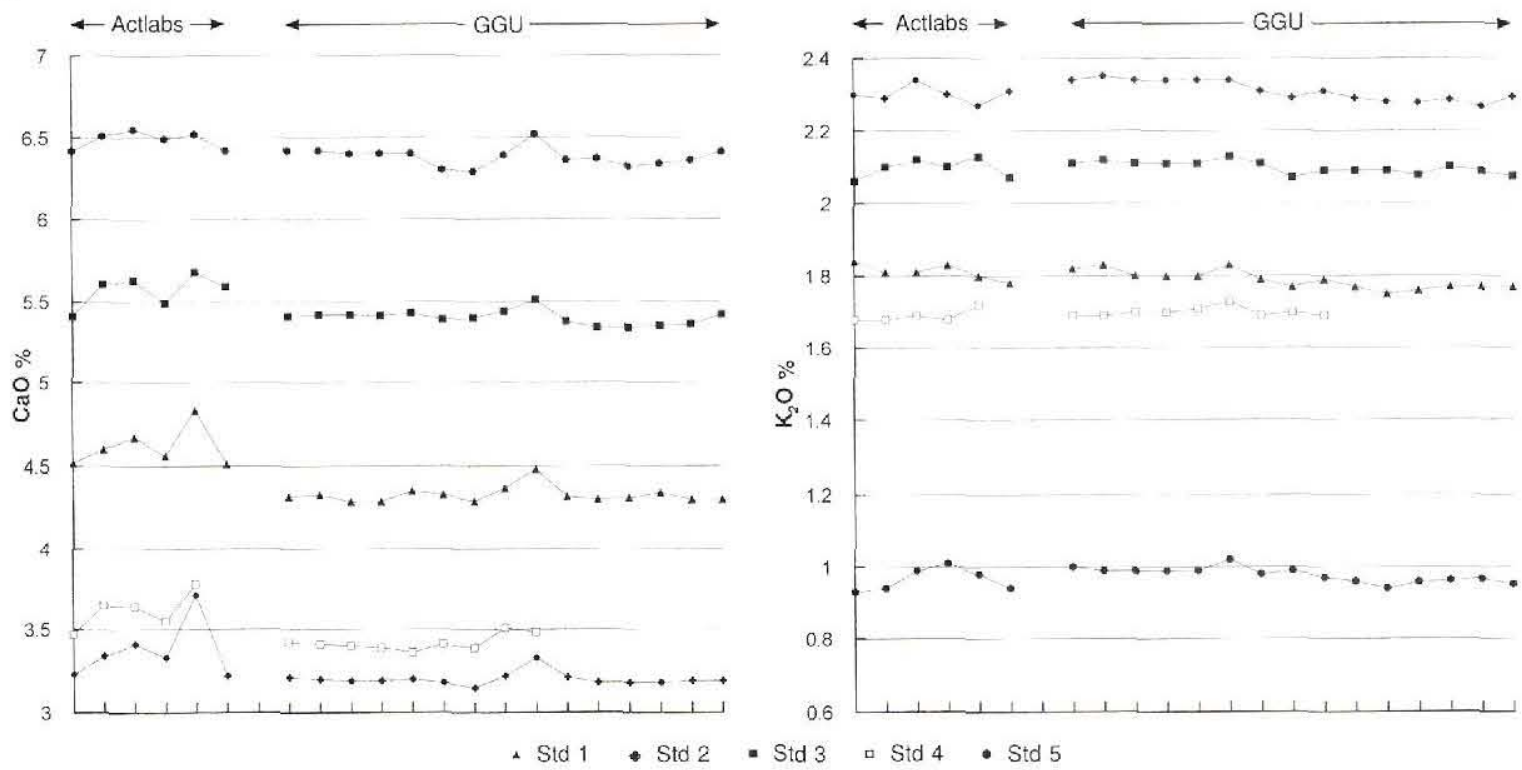

Fig. 5. Chemical variability of $\mathrm{CaO}($ left $)$ and $\mathrm{K}_{2} \mathrm{O}($ right $)$ analyses of 5 internal standard samples conducted at different times from 1990 to 1993. Standard 4 was exhausted during 1992.

Fig. 5 shows the results for $\mathrm{CaO}$ and $\mathrm{K}_{2} \mathrm{O}$ analyses of the five internal standards. A slight variation with time is seen and the parallel shapes of the curves for the five standards, in the case of $\mathrm{Ca}$, indicate that the variation is due to analytical conditions rather than inhomogeneity of the standards. In addition, a difference between laboratories is noted.

The bias between Actlabs and GGU was tested further by

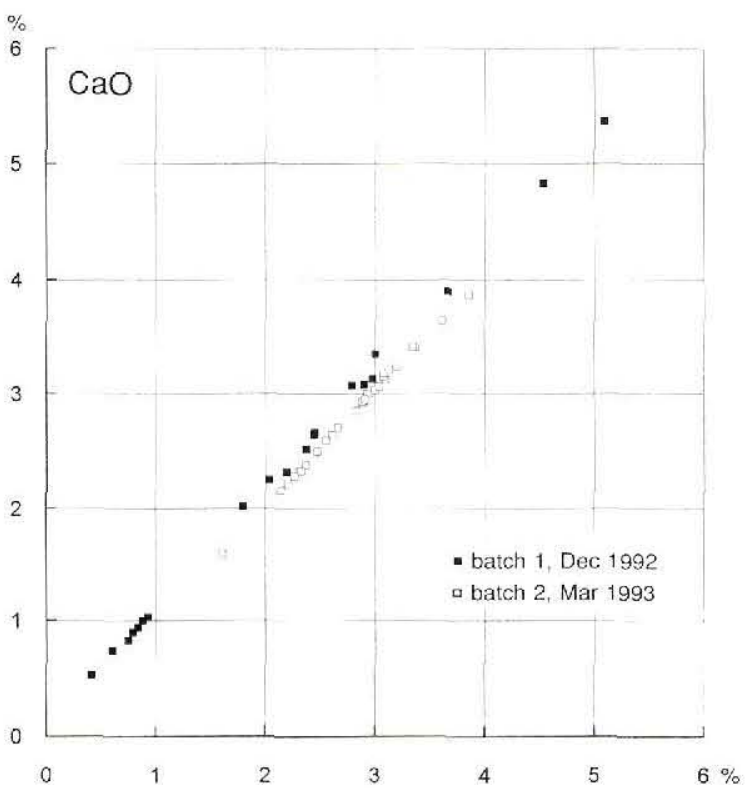

means of two sets of samples which have been analysed at both laboratories at different times (Fig. 6). In both cases there are linear correlations for both $\mathrm{CaO}$ and $\mathrm{K}_{2} \mathrm{O}$ with small deviations from the regression line demonstrating that both laboratories have a fairly good precision and they correlate well within the range of concentrations found in the stream sediments. The data points are close to $x=y$ which means insignificant bias except

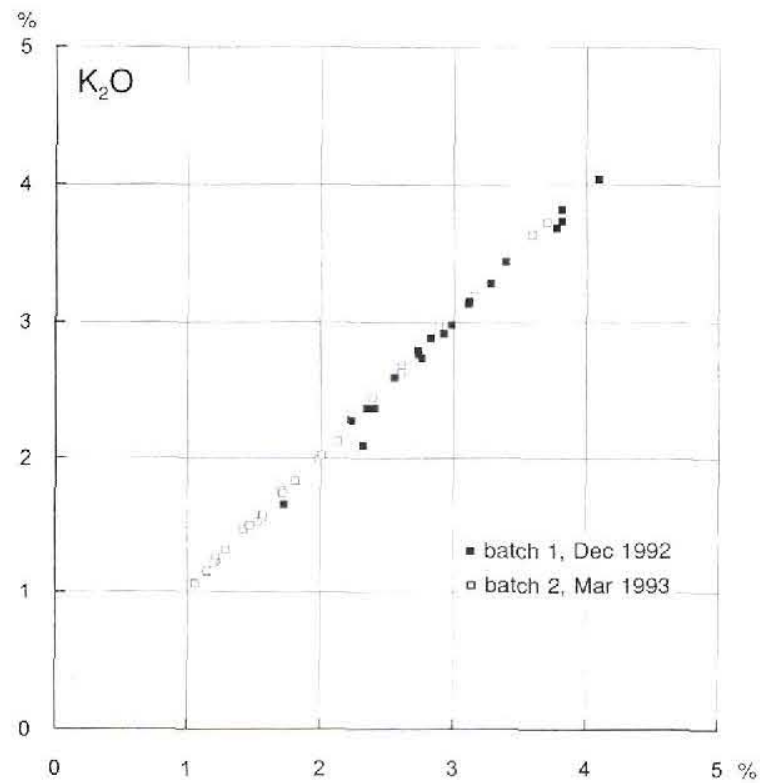

Fig. 6. Comparison between analyses for $\mathrm{CaO}$ (lefi) and $\mathrm{K}_{2} \mathrm{O}$ (right) carried out at Activation Laboratories Ltd. (Actlabs) and Geological Survey of Greenland (GGU). Two sets of samples were analysed at different times. Test 1 is shown in solid symbols and test 2 in open symbols. 
for $\mathrm{CaO}$ in test 1 in which the slope of the regression line deviates from unity (Actlabs values are $c .7 \%$ relatively higher than GGU values). An examination of the temporal variations in both laboratories, as monitored by the standards, showed that test 1 was conducted at a time when the corresponding standard sets deviated $c .7 \%$ relative and test 2 when the standard sets gave almost equal results. Therefore, it is concluded that there is no systematic bias between the laboratories, the main contributor to variations in the analytical values being temporal changes in the laboratory or instrumental conditions. These changes can be monitored satisfactorily using internal standards and the results of replicate analyses of the standards may be used as a basis for calibrating analytical data between batches.

In the case of $\mathrm{K}_{2} \mathrm{O}$, variations are very small with time and between the two laboratories, hence no adjustment between batches is required. In the case of $\mathrm{CaO}$, on the contrary, the batches analysed at Actlabs and one of the batches analysed at GGU (Fig. 5a) deviate from the level defined by the other GGU batches.

The $\mathrm{CaO}$ data from each of the deviating batches are adjusted using the parameters from a linear regression of the analytical values from the corresponding set of standards against the medians of the GGU analyses of the standards. The adjusted values are then used to produce the dot maps (Figs $2 \& 3$ ).

The stream sediment samples contain varying amounts of organic matter which may cause a loss on ignition of 5 to $10 \%$ or more. For this reason the $\mathrm{CaO}$ and $\mathrm{K}_{2} \mathrm{O}$ values presented are calculated as volatile-free concentrations.

Acknowledgments. Thanks are due to sample collectors, helicopter pilots, laboratory personnel, and other persons who have participated in GGU's reconnaissance geochemical mapping programme over the years. Special thanks are due to Else Dam who has been of invaluable assistance in all phases of the programme since 1981. Comments and suggestions by Feiko Kalsbeek and Adam Garde are gratefully acknowledged. The Mineral Resource Administration for Greenland supported the programme financially in 1992 and 1993.

\section{References}

Allaart, J. H. 1975: Geological map of Greenland, 1:500 000, sheet 1, Sydgrønland. Copenhagen: Grønlands Geologiske Undersøgelse.

Allaart, J. H. 1982: Geological map of Greenland, 1:500 000, sheet 2, Frederikshåb Isblink to Søndre Strømfjord. Copenhagen: Grønlands Geologiske Unders $\emptyset$ gelse.

Armour-Brown, A., Steenfelt, A. \& Kunzendorf, H. 1983: Uranium districts defined by reconnaissance geochemistry in South Greenland. J. geochem. Expl. 19, 127-145.

Bølviken, B., Bergström, J., Björklund, A., Kontio, M., Lehmuspelto, P., Lindholm, T., Magnusson, J., Ottesen, R. T., Steenfelt, A. \& Volden, T. 1986: Geochemical atlas of northern Fennoscandia. The Geological Survey of Sweden.

Escher, A. 1971: Geological map of Greenland, 1:500 000, sheet 3, Søndre Strømfjord - Nûgssuaq. Copenhagen: Grønlands Geologiske Undersøgelse.

Friend, C. R. L. \& Nutman, A. P. 1994: Two Archaean granulite facies metamorphic events in the Nuuk-Maniitsoq region, West Greenland: correlation with the Sagleq block, Labrador. J. geol. Soc. London. 151, in press.

Friend, C. R. L., Nutman, A. P. \& McGregor, V. R. 1988: Late Archaean terrane accretion in the Godthăb region, southern West Greenland. Nature 335, 535-538.

Garde, A. A. 1989: Retrogression and fluid movement across a granulite-amphibolite facies boundary in the middle Archaean Nûk gneisses, Fiskefjord, southern West Greenland. In Bridgwater, D. (ed.) Fluid movements - element transport and the composition of the deep crust, 125-137. Dordrecht: Kluwer.

Garde, A. A. \& Steenfelt, A. in press: Geological map of the Precambrian geology of Disko Bugt region. Copenhagen: Grønlands Geologiske Unders $\varnothing$ gelse.

Kalsbeek, F. 1976: Metamorphism of Archaean rocks of West Greenland. In Windley, B. F. (ed.) The early history of the Earth, 225-235. London: John Wiley \& Sons.

Kalsbeek, F. 1990: Disko Bugt Project, central West Greenland. Rapp. Gronlands geol. Unders. 148, 20-24.

Kalsbeek, F. 1993: Use of Rb-Sr isotope data to constrain the time of deposition of Precambrian metasediments: an example from Hamborgerland, West Greenland. Rapp. Gronlands geol. Unders. 159, 95-100.

Kalsbeek, F. 1994: Archaean and early Proterozoic basement provinces in Greenland. Rapp. Gronlands geol. Unders. 160 , $37-40$.

Kalsbeek, F. \& Garde, A. A. 1989: Descriptive text to 1:500 000 sheet 2, Frederikshåb Isblink - Søndre Strømfjord. Copenhagen: Grønlands Geologiske Undersøgelse.

Kalsbeek, F. \& Taylor, P. N. 1985: Isotopic and chemical variation in granites across a Proterozoic continental margin the Ketilidian mobile belt of South Greenland. Earth Planet. Sci. Lett. 73, 65-80.

Kalsbeek, F., Ghisler, M. \& Thomsen, B. 1974: Sand analysis as a method of estimating bedrock compositions in Greenland, illustrated by fluvial sands from the Fiskenæsset region. Bull. Gronlands geol. Unders. 111, 32 pp.

Kalsbeek, F., Pidgeon, R. T. \& Taylor, P. N. 1987: Nagssugtoqidian mobile belt of West Greenland: a cryptic $1850 \mathrm{Ma}$ suture between two Archaean continents - chemical and isotopic evidence. Earth Planet. Sci. Lett. 85, 365-385.

Kalsbeek, F., Larsen, L. M. \& Bondam, J. 1990: Descriptive text to 1:500 000 sheet 1, Sydgrønland. Copenhagen: Grønlands Geologiske Undersøgelse.

Kerr, A. \& Davenport, P. H. 1990: Application of geochemical mapping techniques to a complex Precambrian shield area in Labrador, Canada. J. geochem. Explor. 39, 225-247.

Koljonen, T. (ed.) 1992: The geochemical atlas of Finland, part 2: Till. Espoo: Geological Survey of Finland.

McGregor, V. R., Friend, C. R. L. \& Nutman, A. P. 1991: The late Archaean mobile belt through Godthåbsfjord, southern West Greenland: a continent-continent collision zone? Bull. geol. Soc. Denmark 39, 179-197.

McMillan, W. J., Day, S. \& Matysek, P. F. 1990: Tectonic terranes, metallogeny and regional geochemical surveys; an example from northern British Columbia. J. geochem. Explor. 39, 175-194. 
Patchett, P. J. \& Bridgwater, D. 1984: Origin of continental crust of 1.9-1.7 Ga age defined by $\mathrm{Nd}$ isotopes in the Ketilidian terrain of South Greenland. Contr. Miner. Petrol. 87, 311318.

Plant, J. A., Watson, J. V. \& Green, P. M. 1984: Moine/Dalradian relationships and their palaeotectonic significance. Proc. R. Soc. London, Ser. A 395, 185-202.

Ramberg, H. 1951: Remarks on the average chemical composition of granulite facies and amphibolite-to-epidote amphibolite facies gneisses in West Greenland. Meddr dansk geol. Foren. 12, 27-34.

Steenfelt, A. 1987: Geochemical mapping and prospecting in Greenland - a review of results and experience. $J$. geochem. Explor. 29, 183-205. Steenfelt, A. 1988: Progress in geochemical mapping of West Greenland. Rapp. Gronlands geol. Unders. 140, 17-24.

Steenfelt, A. 1990: Geochemical patterns related to major tectono-stratigraphic units in the Precambrian of northern Scandinavia and Greenland. J. geochem. Explor. 39, 35-48.

Steenfelt, A. 1993: Geochemical mapping - progress in Greenland. J. geochem. Explor. 49, 5-13.

Steenfelt, A. 1994: Large scale geochemical variation in the Precambrian of West and South Greenland. Rapp. Grønlands geol. Unders.

Steenfelt, A. \& Kunzendorf, H. 1979: Geochemical methods in uranium exploration in northern East Greenland. In Watterson, J. R. \& Theobald, P. K. (ed.) Geochemical exploration 1978, 429-442. Ontario: Association of Exploration Geochemists [Spec. Vol. 7].
Steenfelt, A., Thorning, L. \& Tukiainen, T, 1990: Regional compilations of geoscience data from the Nuuk-Maniitsoq area, southern West Greenland. Thematic Map Ser. Grønlands geol. Unders. 90/1.

Steenfelt, A., Dam, E. \& Nielsen, J. P. 1992: Reconnaissance geochemical exploration of map sheet 68 V.2 $\left(67^{\circ} 55^{\prime}\right.$ to $68^{\circ} 45^{\prime} \mathrm{N}, 50^{\circ} 15^{\prime}$ to $52^{\circ} 45^{\prime} \mathrm{W}$ ), West Greenland. Open File Ser. Grønlands geol. Unders. 92/7, 14 pp.

Steenfelt, A., Dam, E. \& Nielsen, J. P. 1993: Reconnaissance geochemical mapping of map sheets $67 \mathrm{~V} .1$ and $68 \mathrm{~V} .1\left(66^{\circ}\right.$ to $68^{\circ} \mathrm{N}, 51^{\circ} 40^{\prime}$ to $54^{\circ} \mathrm{W}$ ), West Greenland. Open File Ser. Grфnlands geol. Unders. 93/1, 16 pp.

Steenfelt, A., Dam, E. \& Petersen, A. 1994a: Reconnaissance geochemical mapping of the Paamiut region $\left(61^{\circ} 25^{\prime}\right.$ to $62^{\circ} 45^{\prime} \mathrm{N}, 48^{\circ} 00^{\prime}$ to $50^{\circ} 00^{\prime} \mathrm{W}$ ), South-West Greenland. Open File Ser. Gronlands geol. Unders. 94/1, 16 pp.

Steenfelt, A., Petersen, A. \& Dam, E. 1994b: Reconnaissance geochemical mapping of the Maniitsoq region $\left(65^{\circ}\right.$ to $66^{\circ} \mathrm{N}$, $51^{\circ} 45^{\prime}$ to $\left.53^{\circ} 30^{\prime} \mathrm{W}\right)$, southern West Greenland. Open File Ser. Grønlands geol. Unders. 94/5, 15 pp.

Taylor, S. R. \& McLennan, S. M. 1985: The continental crust: its composition and evolution. Oxford: Blackwell Scientific Publications.

Upton, B. G. J. \& Emeleus, C. H. 1987: Mid-Proterozoic magmatism in southern Greenland. In Fitton, J. G. \& Upton, B. G. J. (ed.) Alkaline igneous rocks. Spec. Publ. geol. Soc. Lond. 30, 449-471.

Windley, B. F. 1984: The evolving continents, 339 pp. 2nd ed. Chichester: John Wiley \& Sons. 